\title{
Mutu Beras dan Nasi Jagung Putih Lokal Varietas Anoman 1 dalam Kemasan Edibel dengan Ketebalan Berbeda
}

\section{(The Quality of Dried and Cooked Local White Corn Rice of Anoman 1 Variety in Edible Packaging with Different Thickness)}

\author{
Rahmawati Rahmawati*, Astri Yaniansah
}

(Diterima Juli 2020/Disetujui Desember 2020)

\begin{abstract}
ABSTRAK
Beras merupakan makanan pokok kebanyakan masyarakat Indonesia. Perkembangan pada saat ini, masyarakat menginginkan makanan pokok yang tidak hanya mengenyangkan, namun juga tidak meningkatkan kadar gula darah (indeks glikemik rendah). Salah satu bahan pangan yang mengandung pati lebih tinggi, tetapi dengan indeks glikemik yang lebih rendah dan serat yang lebih tinggi dibandingkan dengan beras adalah jagung putih. Warna putih pada jagung menjadi kelebihan karena jika dibuat dalam bentuk grits dapat menyerupai beras. Kelemahan jagung putih adalah lebih keras dibandingkan dengan beras. Untuk memperlunak dan memudahkan pada saat konsumsi maka jagung putih dilapisi dengan pengemas edibel berbahan tapioka. Tujuan penelitian ini ialah mempelajari (1) mutu beras jagung kering berbahan jagung putih lokal varietas Anoman 1 dalam kemasan edibel dengan ketebalan kemasan 0,$7 ; 0,9 ; 1,1 ; 1,3$; dan $1,5 \mathrm{~mm}$; (2) mutu nasi jagung setelah dimasak. Hasil penelitian menunjukkan bahwa ketebalan kemasan edibel secara nyata memengaruhi kadar air, kadar abu, kadar protein, kadar lemak, dan kadar karbohidrat beras jagung kering serta semua parameter pada nasi jagung $(\alpha=0.05)$. Nasi jagung terbaik berdasarkan uji kepulenan, dihasilkan oleh nasi jagung yang dilapisi dengan kemasan edibel ketebalan 1,5 mm. Karakteristik (1) mutu beras jagung kering terbaik adalah kadar air 11,39\%, abu 0,21\% db, protein 15,23\% $\mathrm{db}$, lemak $0,53 \% \mathrm{db}$, karbohidrat $72,64 \%$, dan serat kasar $2,11 \%$, (2) mutu nasi jagung adalah kepulenan $18,17 \mathrm{~g} / \mathrm{mm}^{2}$, berwarna kekuningan (skor 1,1), aroma agak khas jagung (skor 2,5), tekstur agak pulen (skor 3,4$)$, dan rasa manis agak kuat (skor 2,8$)$.
\end{abstract}

Kata kunci: beras, jagung putih Anoman 1, kemasan edibel, ketebalan, tapioka

\section{ABSTRACT}

Rice is a staple food for most Indonesian population. Nowadays, people want staple foods that are not only filling but also do not increase blood sugar concentration (low glycemic index). One of foods that contain higher starch, lower glycemic index, and higher fiber than rice is white corn. The white color of the corn is an advantage because if it is made in grits it can resemble rice. Weakness of white corn is harder than rice. To soften and make it easier to consume, it is coated with an edible packaging made from tapioca. The purposes of this study were to study (1) the quality of dried corn rice from local white corn Anoman 1 variety in edible packaging with packaging thickness of 0.7 , $0.9,1.1,1.3$, and $1.5 \mathrm{~mm}$; (2) the quality of cooked white corn rice produced. The results showed that the thickness of the edible packaging significantly affected (1) the moisture, ash, protein, fat, and carbohydrate contents of dried white corn rice and (2) all parameters of cooked white corn rice $(\alpha=0.05)$. The best cooked corn rice based on the stickiness test was found in coated dried corn rice with edible packaging with a thickness of $1.5 \mathrm{~mm}$. Characteristics of (1) dried white corn rice contained $11.39 \%$ water, $0.21 \% \mathrm{db}$ ash, $15.23 \% \mathrm{db}$ protein, $0.53 \% \mathrm{db}$ fat, $72.64 \%$ carbohydrates, $2.11 \%$ crude fiber, (2) the quality of cooked of white corn rice were $18.17 \mathrm{~g} / \mathrm{mm} 2$ stickiness, yellowish color (score 1.1), slightly distinctive aroma of corn (score 2.5), slightly fluffier texture (score 3.4), and rather strong sweet taste (score 2.8).

Keywords: edible packaging, local white corn Anoman 1, rice, stickiness, tapioca

\section{PENDAHULUAN}

Beras merupakan makanan pokok kebanyakan masyarakat Indonesia. Seperti diketahui bahwa populasi masyarakat Indonesia meningkat dari tahun ke tahun. Hal ini menyebabkan kebutuhan akan beras juga meningkat. Sementara itu, lahan dan persediaan

Program Studi Teknologi Pangan, Universitas Sahid, Jl Prof. Supomo no. 84 Jakarta, Indonesia 12870

* Penulis Korespondensi:

Email: rahmafarasara@usahid.ac.id beras terbatas. Berdasarkan hal ini, penting dilakukan diversifikasi pangan untuk menyediakan makanan pokok, khususnya menggunakan bahan pangan lokal. Selain itu, perkembangan pada saat ini menunjukkan bahwa masyarakat menginginkan makanan pokok yang tidak hanya mengenyangkan, namun juga tidak meningkatkan gula darah (indeks glikemik [IG] yang lebih rendah dari beras) dan mengandung serat yang lebih tinggi dibandingkan dengan beras.

Salah satu bahan pangan lokal yang sesuai dengan minat masyarakat adalah jagung putih lokal. Jagung putih lokal sedang dikembangkan oleh Balai 
Penelitian dan Pengembangan Pertanian karena mengandung pati yang tinggi, mempunyai poduktivitas yang lebih tinggi dibandingkan dengan jagung kuning serta lebih tahan terhadap kekeringan (Qanytah \& Prastuti 2008). Selain itu, biji jagung putih lokal, khususnya varietas Anoman 1, memiliki indeks glikemik rendah, yaitu 36,40 (Richana et al. 2011) dibandingkan dengan beras, dengan indeks glikemik 63,50-97,29 (Widowati et al. 2009), yang mengandung pati lebih tinggi, yaitu $85,27 \%$ (Suarni et al. 2013) dibandingkan beras $78,10 \%$ (Ekasari 2007) dengan daya cerna pati jagung putih $65,44 \%$ (Richana et al. 2011) yang lebih rendah dibandingkan dengan beras, yaitu $72,88 \%$ (Widowat et al. 2009), dan serat pangan yang lebih tinggi, yaitu 6,62 \% (Richana et al. 2011) dibandingkan dengan beras, yaitu 5,69\% (Widowati et al. 2009).

Pemanfaatan jagung putih sebagai beras mempunyai peluang yang baik karena warna putih pada jagung menjadi suatu kelebihan, yaitu jika dibuat dalam bentuk grits dapat menyerupai beras. Selain kelebihan, jagung putih juga mempunyai kelemahan, yaitu butiran bijinya lebih keras dibandingkan dengan jagung kuning dan beras karena kandungan patinya yang lebih tinggi. Untuk melunakkan biji jagung putih lokal varietas Anoman 1, Farasara et al. (2014) melakukan perendaman dalam air dan membuat menjadi grits. Pemanfaatan jagung sebagai beras jagung, memerlukan modifikasi di mana masyarakat pada saat ini lebih memilih bahan pangan yang mudah dan cepat disajikan. Untuk memenuhi keinginan masyarakat maka dibuat beras jagung dalam kemasan film edibel untuk satu porsi makan $(50 \mathrm{~g})$. Secara umum, kemasan pangan berperan untuk melindungi produk pangan dari kerusakan fisik, kimia, dan biologis dengan cara memperlambat kerusakan, mempertahankan mutu, dan memperpanjang umur simpan sehingga produk tetap aman dikonsumsi (Marsh \& Bugusu 2007).

Pembuatan beras jagung kering dalam kemasan edibel akan mempermudah konsumen dalam menyiapkan dan mengkonsumsinya. Beras jagung dapat langsung dimasak (direbus atau dimasak dengan rice cooker) dan dikonsumsi dengan lauk lainnya. Untuk membuat kemasan film edibel digunakan bahan baku pati singkong (tapioka) karena tapioka mudah ditemukan, banyak tersedia, murah, dapat didegradasi oleh tanah, dapat dimakan, dan dapat melindungi makanan dari kerusakan karena lingkungan (Bersaneti et al. 2016). Selain itu, karena tapioka mengandung amilopektin tinggi, yaitu $91.94 \%$ dari kandungan pati (Imanningsih 2012), diharapkan dapat memperlunak beras jagung pada saat pemasakan. Akan tetapi, pembuatan kemasan film edibel dari tapioka saja akan menghasilkan lapisan kemasan yang rapuh dan memiliki kekuatan mekanik dan stabilitas panas yang buruk. Hal ini karena pati bersifat hidrofilik kuat yang membuat bahan menjadi sensitif ketika bersentuhan dengan air (Avella et al. 2005). Berdasarkan hal tersebut maka kemasan film edibel dari tapioka ditambahkan plasticizer. Plasticizer akan meningkatkan fleksibilitas pati dengan mengurangi gaya intermolekuler dalam matriks polimer sehingga meningkatkan mobilitas rantai polimer yang akan meningkatkan fleksibilitas kemasan film (Sanyang et al. 2016). Jenis plasticizer yang umum digunakan untuk membentuk film pati adalah senyawa hidrofilik golongan poliol, yaitu sorbitol dan gliserol (Zhang \& Han 2006).

Hasil penelitian Zahiruddin et al. (2019) tentang penggunaan plasticizer sorbitol pada film tapioka menghasilkan kekuatan tarik yang lebih besar $(18,92$ $\mathrm{MPa})$ dibandingkan dengan gliserol (15,84 $\mathrm{MPa})$, namun lebih rendah dibandingkan dengan kontrol $(33,29 \mathrm{MPa})$. Hal ini terjadi karena sorbitol memiliki bobot dan ukuran molekul yang lebih besar sehingga meningkatkan mobilitas molekul amorf dan kristalisasi matriks pati (Mali et al. 2005). Hal ini menyebabkan film yang dihasilkan kuat dan kaku, serta kurang fleksibel dibandingkan dengan penggunaan gliserol. Akan tetapi, karena pada penelitian ini diinginkan kemasan yang kuat dan kaku maka sorbitol dipilih sebagai platicizer. Untuk meningkatkan kekuatan kemasan film edibel maka pada penelitian ini ditambahkan sodium alginat. Secara umum, alginat termasuk ke dalam kelompok GRAS (generally regarded as safe atau bahan yang dianggap aman) sehingga aman digunakan (USFDA 2019). Selain itu, alginat digunakan secara luas di industri makanan, minuman, tekstil, printing, dan farmasi sebagai bahan pengental, penstabil, pengemulsi, bahan pengkelat, enkapsulasi, pengembang, atau digunakan sebagai bahan pembentuk gel, film, dan membran (Parreidt et al. 2018).

Berdasarkan uraian di atas maka tujuan penelitian ini adalah untuk mempelajari (1) mutu beras jagung kering berbahan jagung putih lokal varietas Anoman 1 dalam kemasan edibel dengan ketebalan kemasan 0,$7 ; 0,9 ; 1,1 ; 1,3$; dan 1,5 mm; (2) mutu nasi jagung setelah dimasak. Mutu beras jagung ditentukan berdasarkan kadar air, abu, protein, lemak, karbohidrat, dan serat kasar, sedangkan mutu nasi jagung ditentukan berdasarkan uji kepulenan, mutu hedonik warna, aroma, tektur, dan rasa, serta uji rangking berdasarkan tingkat kepulenan.

\section{METODE PENELITIAN}

\section{Bahan dan Alat}

Bahan utama yang digunakan dalam penelitian ini adalah jagung putih lokal varietas Anoman 1 yang diperoleh dari Balai Penelitian Serealia Maros, Sulawesi, Indonesia. Selain itu, bahan-bahan lain yang digunakan adalah air minum, pati tapioka (food grade), natrium alginat (food grade), sorbitol (food grade), dan ragi instan komersial.

Alat-alat yang digunakan pada pembuatan beras jagung putih lokal dalam kemasan edibel adalah timbangan analitik, alat-alat gelas, alat pengolahan, 
alat analisis, Spektrofotometer UV-VIS, Micrometer skrup, dan CT3 Texture Analyzer-Ametek Brookfield.

\section{Lokasi Penelitian}

Penelitian pembuatan beras jagung dan kemasan edible film dilakukan di Laboratorium Pangan PT Kino Indonesia, Tbk Jakarta. Uji organoleptik nasi jagung dilakukan di Laboratorium Pengolahan Pangan Universitas Sahid, Jakarta. Uji kimia dan uji fisik beras jagung dilakukan di laboratorium uji.

\section{Metode Penelitian}

Penelitian dilakukan beberapa tahap. Tahap 1 adalah pembuatan beras jagung, tahap 2 adalah pembuatan kemasan edibel, tahap 3 adalah pembuatan beras jagung kering dalam kemasan edibel, dan tahap 4 adalah memasak beras jagung kering dalam kemasan edibel. Prosedur pembuatannya diuraikan di bawah ini.

Tahap 1. Pembuatan Beras Jagung Putih Lokal varietas Anoman 1 (modifikasi Sugiyono et al. (2004); Richana \& Suarni (2005); Husain, et al. (2006); Wijaya (2013))

Kernel jagung putih dibuat menjadi grits berukuran lolos saringan ukuran 20 mesh. Setelah itu grits direndam dalam air (1:2) selama 48 jam pada suhu ruang. Perendaman grits jagung dalam air yang mengandung ragi instant komersial sebanyak 0,25\% untuk memperlunak grits. Selanjutnya, grits jagung direbus dengan air (1:3) pada suhu $100^{\circ} \mathrm{C}$ selama 10 menit sampai air rebusan habis untuk mematangkan grits. Grits jagung yang sudah direbus dikukus pada suhu $100^{\circ} \mathrm{C}$ selama 30 menit untuk meningkatkan kematangan dan porositas sehingga lebih empuk. Untuk membentuk struktur beras jagung agar tidak menggumpal pada saat dikeringkan maka grits jagung matang dibekukan pada suhu $-20^{\circ} \mathrm{C}$ selama $10-12$ jam. Lalu grits jagung matang dikeringkan dengan oven pada suhu $40^{\circ} \mathrm{C}$ selama 24 jam.

\section{Tahap 2. Pembuatan Kemasan Edibel (Modifikasi Wijaya, 2013)}

Empat gram pati tapioka dilarutkan dalam air sebanyak $30 \mathrm{~mL}$ hingga larut dan $1 \mathrm{~mL}$ sorbitol dimasukkan ke dalam larutan pati dan diaduk hingga homogen sambil dipanaskan sampai suhu $40^{\circ} \mathrm{C}$. Kemudian dilakukan pelarutan 1 gram natrium alginat dalam $20 \mathrm{~mL}$ air panas pada gelas piala yang berbeda dan dilakukan pengadukan sampai homogen. Selanjutnya, larutan natrium alginat ditambahkan ke dalam larutan pati yang telah terplastisasi sorbitol dan diaduk hingga homogen menggunakan pengaduk magnetik dengan pemanasan mencapai suhu $65^{\circ} \mathrm{C}$. Setelah homogen, larutan film didiamkan pada suhu kamar $\left(20-25^{\circ} \mathrm{C}\right)$ selama 10 menit dan sesekali diaduk agar terbebas dari gelembung udara. Kemudian larutan film dicetak di atas pelat kaca. Larutan film dicetak agar mendapatkan ketebalan $0,7 \mathrm{~mm}, 0,9 \mathrm{~mm}$, $1,1 \mathrm{~mm}, 1,3 \mathrm{~mm}$, dan $1,5 \mathrm{~mm}$. Lapisan film panas dikeringkan dengan didiamkan pada suhu ruang (20$25^{\circ} \mathrm{C}$ ) selama $48 \mathrm{jam}$.

\section{Tahap 3. Pembuatan Beras Jagung Kering dalam Kemasan Edibel}

Setiap lembar lapisan edibel diisi 1 porsi beras jagung kering per penyajian, yaitu $50 \mathrm{~g}$. Selanjutnya bagian tepi lapisan kemasan edibel dikelim dengan dipanaskan pada bagian tepinya.

\section{Tahap 4. Pemasakan nasi jagung}

Nasi jagung dimasak dengan menambahkan air 1:3 dan dimasak dengan rice cooker.

\section{Pengujian Mutu Beras Jagung Putih dalam Kemasan Edibel}

Mutu beras jagung dalam kemasan edibel ditentukan berdasarkan uji kadar air, kadar abu, kadar protein, kadar lemak, kadar karbohidrat (AOAC 2006), dan kadar serat kasar (SNI 01-2891-1992-BSN, 1992).

\section{Pengujian Mutu Nasi Jagung Putih dalam Kemasan Edibel}

Mutu nasi jagung putih dalam kemasan edibel ditentukan berdasarkan uji kepulenan (Suyatma 2010). Selain itu, nasi diuji secara organoleptik, dengan uji mutu hedonik untuk parameter warna, aroma, kepulenan, dan rasa serta uji rangking berdasarkan tingkat kepulenan nasi jagung (Meilgaard et al. 2015).

\section{Analisis Data}

Penelitian diulang 3 kali dan data hasil penelitian dianalisis dengan Analysis of Variance (ANOVA) menggunakan program SPSS versi 20. Jika perlakuan memengaruhi mutu secara signifikan, maka dilakukan uji lanjut dengan Duncan Multiple Range Test (DMRT).

\section{HASIL DAN PEMBAHASAN}

\section{Mutu Beras Jagung Putih dalam Kemasan Edibel}

Mutu beras jagung putih lokal varietas Anoman 1 dalam kemasan edibel ditentukan berdasarkan uji kadar air, kadar abu, kadar protein, kadar lemak, kadar karbohidrat, dan kadar serat kasar. Data hasil pengukuran ini disajikan pada Tabel 1.

\section{- Kadar air}

Kadar air beras jagung putih lokal dalam film kemasan edibel berkisar antara 9,6-11,4\%, di mana kadar air cenderung meningkat seiring dengan peningkatan ketebalan lapisan kemasan edibel (Tabel 1). Hasil uji statistik menunjukkan bahwa ketebalan lapisan film kemasan edibel memengaruhi kadar air beras jagung secara nyata $(\alpha=0,05)$. Hal ini sejalan dengan temuan Resianingrum et al. (2016) di mana lapisan film edibel dari pati singkong yang bersifat hidrofilik mempunyai laju transmisi uap air yang meningkat dengan semakin tingginya lapisan pati. 
Tabel 1 Mutu beras jagung putih lokal varietas Anoman 1 dalam kemasan edibel

\begin{tabular}{lccccc}
\hline \multirow{2}{*}{ Parameter (\%) } & \multicolumn{5}{c}{ Ketebalan lapisan kemasan edibel $(\mathrm{mm})$} \\
\cline { 2 - 6 } & 0.7 & 0.9 & 1.1 & 1.3 & 1.5 \\
\hline Kadar air & $9,60 \pm 0,64^{\mathrm{a}}$ & $10,13 \pm 0,03^{\mathrm{a}}$ & $10,81 \pm 0,05^{\mathrm{a}}$ & $11,27 \pm 0,26^{\mathrm{b}}$ & $11,39 \pm 0,04^{\mathrm{b}}$ \\
Kadar abu (db) & $0,20 \pm 0,05$ & $0,14 \pm 0,02$ & $0,15 \pm 0,01$ & $0,20 \pm 0,06$ & $0,21 \pm 0,01$ \\
Kadar protein (db) & $15,86 \pm 0,48^{\mathrm{bc}}$ & $15,68 \pm 0,03^{\mathrm{a}}$ & $15,53 \pm 0,23^{\mathrm{c}}$ & $15,37 \pm 0,22^{\mathrm{bc}}$ & $15,23 \pm 0,03^{\mathrm{ab}}$ \\
Kadar lemak (db) & $0,71 \pm 0,01^{\mathrm{a}}$ & $0,71 \pm 0,05^{\mathrm{a}}$ & $0,72 \pm 0,13^{\mathrm{a}}$ & $0,61 \pm 0,05^{\mathrm{b}}$ & $0,53 \pm 0,08^{\mathrm{b}}$ \\
Karbohidrat & $73,63 \pm 0,78^{\mathrm{a}}$ & $73,34 \pm 0,21^{\mathrm{ab}}$ & $72,79 \pm 0,22^{\mathrm{ab}}$ & $72,55 \pm 0,25^{\mathrm{b}}$ & $72,64 \pm 0,73^{\mathrm{c}}$ \\
Serat kasar & $2,21 \pm 0,04$ & $2,19 \pm 0,04$ & $2,16 \pm 0,03$ & $2,14 \pm 0,15$ & $2,11 \pm 0,14$ \\
\hline
\end{tabular}

Keterangan: Nilai rata-rata pada baris yang sama yang diikuti oleh huruf yang sama pada kolom notasi menunjukkan perbedaan tidak nyata pada $\alpha=0,05$ (DMRT).

Peningkatan kadar air yang tidak terlalu besar $(1,8 \%)$ terjadi karena lapisan film kemasan edibel menggunakan sorbitol sebagai plasticizer, dan sorbitol mempunyai kemampuan yang lebih rendah untuk menyerap air dari lingkungan dibandingkan dengan gliserol (Galdeano et al. 2013). Selain itu, adanya alginat sebagai bahan baku penyusun kemasan film edibel akan menghasilkan gel yang berporos dengan sifat penahan air yang baik (Parreidt et al. 2018).

\section{- Kadar abu}

Kadar abu beras jagung putih lokal dalam film kemasan edibel berkisar antara $0,14-0,21 \%$, di mana kadar abu relatif sama walaupun terjadi peningkatan dengan semakin tebalnya lapisan kemasan (Tabel 1). Hasil uji statistik menunjukkan bahwa ketebalan lapisan filem edibel tidak secara nyata memengaruhi kadar abu beras jagung $(\alpha=0,05)$. Kadar abu yang diperoleh pada penelitian ini lebih rendah dari hasil yang dilaporkan oleh Suarni \& Firmansyah (2005), yaitu kadar abu beras jagung yang dihasilkan antara $1,64-1,89 \%$. Rendahnya kadar abu pada beras jagung dalam kemasan film edibel diduga dipengaruhi oleh proses pembuatan grits. Seperti diketahui bahwa kandungan mineral terbesar pada biji jagung terdapat pada lembaga. Pada proses pembuatan grits, di mana biji dipecah dan selanjutnya dicuci, menyebabkan lembaga terlepas dari endosperm biji jagung sehingga mengurangi kadar abu. Selain itu, kadar abu yang rendah yang diperoleh pada penelitian ini juga dapat disebabkan oleh kadar abu dalam penyusun film kemasan edibel, yaitu pati tapioka, yang mempunyai kadar maksimum sebesar 0,6\% (BSN 1994).

\section{- Kadar protein}

Kadar protein beras jagung putih lokal dalam film kemasan edibel berkisar antara 15,23-15,86\% db, di mana kadar protein cenderung menurun seiring dengan peningkatan ketebalan lapisan kemasan edibel (Tabel 1). Hasil uji statistik menunjukkan bahwa ketebalan lapisan film kemasan edibel secara nyata memengaruhi kadar protein beras jagung $(\alpha=0,05)$. Kadar protein tapioka lebih rendah, yaitu 1,1\% (Kemenkes 2017), dibandingkan dengan grits jagung, yaitu 5,27\% (Rahmawati et al. 2018). Dengan demikian, semakin tebal lapisan film edibel kemasan, akan semakin menurun kadar protein beras jagung putih kering. Selain itu, menurut Suarni dan Widowati (2007), protein endosperma jagung terdiri atas lima fraksi berdasarkan kelarutannya, yaitu (1) albumin (protein larut air) sebanyak 7\%; (2) globulin (protein larut garam) sebanyak 5\%; (3) nitrogen nonprotein sebanyak 6\%; (4) prolamin atau zein (protein larut alkohol konsentrasi tinggi) sebanyak $52 \%$; dan (5) glutelin (protein larut alkali) sebanyak $26 \%$. Sisanya sekitar $5 \%$ adalah residu nitrogen. Dengan adanya proses perendaman pada saat pembuatan grits menyebabkan protein yang larut air akan larut pada air perendam. Hal ini akhirnya akan menurunkan kadar protein jagung.

\section{- Kadar lemak}

Kadar lemak beras jagung putih lokal dalam film kemasan edibel berkisar antara $0,53-0,71 \% \mathrm{db}$, di mana kadar lemak cenderung meningkat seiring dengan peningkatan ketebalan lapisan kemasan edibel (Tabel 1). Hasil uji statistik menunjukkan bahwa ketebalan lapisan film kemasan edibel secara nyata memengaruhi kadar lemak beras jagung $(\alpha=0,05)$. Kadar lemak tapioka adalah 0,5\% (Kemenkes 2017) yang lebih rendah dibandingkan dengan kadar lemak grits jagung, yaitu 5,02\% (Rahmawati et al. 2018). Dengan demikian, semakin tebal lapisan film edibel kemasan, semakin menurun juga kadar lemak beras jagung putih kering. Selain itu, secara umum, lemak banyak terdapat pada bagian germ jagung. Pada saat pembuatan grits, bagian germ banyak yang terbuang. Hal ini menyebabkan kadar lemak beras jagung kering menjadi relatif rendah.

\section{- Kadar karbohidrat}

Kadar karbohidrat beras jagung putih lokal dalam film kemasan edibel berkisar antara $72,64-73,63 \% \mathrm{db}$, di mana kadar karbohidrat cenderung menurun seiring dengan peningkatan ketebalan lapisan kemasan edibel (Tabel 1). Hasil uji statistik menunjukkan bahwa ketebalan lapisan film kemasan edibel secara nyata memengaruhi kadar karbohidrat beras jagung $(\alpha=$ $0,05)$. Kadar karbohidrat tapioka lebih tinggi, yaitu $88,20 \%$ (Kemenkes 2017) dibandingkan dengan grits jagung, yaitu $75,10 \%$ (Rahmawati et al. 2018). Dengan demikian, semakin tebal lapisan film edibel kemasan maka secara total persentase akan menurunkan kadar karbohidrat beras jagung putih kering. 


\section{- Kadar serat kasar}

Kadar serat kasar beras jagung putih lokal dalam film kemasan edibel berkisar antara 2,11-2,21\% db, di mana kadar serat kasar cenderung menurun seiring dengan peningkatan ketebalan lapisan kemasan edibel (Tabel 1). Penurunan kadar serat kasar pada beras jagung putih kering dalam kemasan diduga terkait dengan kadar serat kasar tapioka yang lebih rendah, yaitu $0,9 \%$ (Kemenkes 2017) dibandingkan dengan jagung putih lokal varietas Anoman 1, yaitu 9,27\% bk (Rahmawati et al. 2013). Selain itu, kandungan serat kasar natrium alginat juga lebih rendah dibandingkan jagung putih, yaitu 2,16-3,19\% (Peranginangin et al. 2015).

\section{Mutu Nasi Jagung Putih dalam Kemasan Edibel setelah Dimasak}

Mutu nasi jagung dalam kemasan edibel ditentukan berdasarkan uji kepulenan dan uji sensori. Uji sensori terdiri atas uji mutu hedonik untuk parameter warna, aroma, kepulenan, dan rasa serta uji rangking berdasarkan tingkat kepulenan nasi jagung. Data disajikan pada Tabel 2 dan 3.

\section{- Kepulenan nasi jagung putih dalam kemasan film edibel}

Kepulenan nasi jagung dalam kemasan film edibel berkisar antara 9,80-18,17 g/mm², di mana kepulenan nasi jagung cenderung meningkat seiring dengan peningkatan ketebalan lapisan kemasan edibel (Tabel 2). Hasil uji statistik menunjukkan bahwa ketebalan lapisan film kemasan edibel secara nyata memengaruhi kepulenan nasi jagung $(\alpha=0,05)$. Secara umum, kepulenan pada nasi dipengaruhi oleh kandungan amilopektin bahan. Semakin tinggi kadar amilopektin maka nasi akan semakin pulen. Nasi ketan lebih pulen dibandingkan dengan nasi biasa. Kandungan amilopektin beras ketan (>77\%) yang lebih tinggi dibandingkan beras biasa $(<75 \%$ ) (Winarno 1997). Pada nasi jagung putih, kemasan film edibel dibuat dari tapioka yang memiliki kandungan amilopektin 91,94\% (Imanningsih 2012). Dengan demikian, semakin tebal lapisan film kemasan akan meningkatkan kepulenan nasi jagung.

\section{Mutu Sensori Nasi Jagung}

Mutu sensori nasi jagung dalam kemasan film edible dinilai berdasarkan warna, aroma, tekstur, dan rasanya (Tabel 3). Warna nasi jagung dalam kemasan film edible berkisar antara agak putih sampai kekuningan (skor 1,1-2,5), di mana semakin tebal lapisan kemasan film edibel menyebabkan warna semakin kekuningan. Pada saat pemanasan, kandungan pati pada beras jagung dan kemasan film edibel akan terurai menjadi gula sederhana. Selain pati, jagung mengandung protein yang akan terurai menjadi asam amino pada saat pemanasan. Adanya gula sederhana, khususnya gula pereduksi dan gugus amina, pada nasi jagung menyebabkan potensi terjadinya reaksi Maillard (Lund \& Ray 2017). Reaksi Maillard akan menghasilkan senyawa melanoidin yang berwarna cokelat (Yu et al. 2018). Dengan semakin tebalnya lapisan kemasan film edibel maka menyebabkan reaksi pencokelatan semakin besar sehingga warna nasi jagung menjadi lebih kekuningan.

Aroma nasi jagung adalah agak khas nasi jagung (skor 2,5-2,9), di mana aroma nasi jagung relatif sama untuk semua ketebalan lapisan film edible. Secara umum, aroma khas jagung putih relatif tidak kuat dan menguap pada saat pemanasan. Hasi uji Anova menunjukkan bahwa ketebalan lapisan kemasan edibel tidak nyata memengaruhi aroma nasi jagung ( $\alpha$ $=0,05)($ Table 1$)$.

Tekstur nasi jagung dalam kemasan edibel berkisar antara sangat pera sampai agak pulen (skor 1,4-3,4), di mana tekstur nasi jagung akan semakin pulen

Tabel 2 Nilai rata-rata kepulenan $\left(\mathrm{g} / \mathrm{mm}^{2}\right)$ nasi jagung dalam kemasan film edibel

\begin{tabular}{|c|c|c|c|c|c|}
\hline \multirow{2}{*}{ Mutu } & \multicolumn{5}{|c|}{ Ketebalan edible film (mm) } \\
\hline & 0,7 & 0,9 & 1,1 & 1,3 & 1,5 \\
\hline Kepulenan & $9,80 \pm 2,24^{a}$ & $11,25 \pm 1,04^{b}$ & $12,76 \pm 2,74^{c}$ & $15,75 \pm 2,78^{d}$ & $18,17 \pm 1,06^{e}$ \\
\hline
\end{tabular}

Tabel 3 Nilai rata-rata mutu sensori (skor) nasi jagung dalam kemasan film edibel

\begin{tabular}{lccccc}
\hline \multirow{2}{*}{ Mutu } & \multicolumn{5}{c}{ Ketebalan edible film $(\mathrm{mm})$} \\
\cline { 2 - 6 } & 0,7 & 0,9 & 1,1 & 1,3 & 1,5 \\
\hline Warna & $2,50 \pm 0,15^{\mathrm{c}}$ & $2,40 \pm 0,15^{\mathrm{cb}}$ & $2,20 \pm 0,25^{\mathrm{b}}$ & $1,40 \pm 0,20^{\mathrm{a}}$ & $1,10 \pm 0,11^{\mathrm{a}}$ \\
Aroma & $2,90 \pm 0,15$ & $2,70 \pm 0,15$ & $2,60 \pm 0,12$ & $2,60 \pm 0,06$ & $2,50 \pm 0,27$ \\
Tekstur & $1,40 \pm 0,20^{\mathrm{a}}$ & $1,90 \pm 0,67^{\mathrm{ab}}$ & $2,50 \pm 0,27^{\mathrm{bc}}$ & $2,90 \pm 0,27^{\mathrm{c}}$ & $3,40 \pm 0,38^{\mathrm{c}}$ \\
Rasa & $1,30 \pm 0,21^{\mathrm{a}}$ & $1,70 \pm 0,00^{\mathrm{a}}$ & $2,10 \pm 0,21^{\mathrm{ab}}$ & $2,30 \pm 0,10^{\mathrm{ab}}$ & $2,80 \pm 0,25^{\mathrm{b}}$ \\
Uji rangking & $5^{\mathrm{a}}$ & $4^{\mathrm{a}}$ & $3^{\mathrm{b}}$ & $2^{\mathrm{c}}$ & $1^{\mathrm{d}}$ \\
\hline
\end{tabular}

Keterangan: Nilai rata-rata pada baris yang sama yang diikuti oleh huruf yang sama pada kolom notasi menunjukkan perbedaan tidak nyata pada $\alpha=0,05$ (DMRT). Warna: $5=$ sangat putih, $4=$ putih, $3=$ agak putih, $2=$ putih kekuningan, 1 = kekuningan; Aroma: 5 = sangat khas nasi jagung, $4=$ khas nasi jagung, $3=$ agak khas nasi jagung, 2 = tidak khas nasi jagung, 1 = sangat tidak khas nasi jagung; Tekstur: 5 = sangat pulen, $4=$ pulen, 3 = agak pulen, 2 = agak pera, $1=$ sangat pera; Rasa: 5 = manis sangat kuat, $4=$ manis kuat, $3=$ manis agak kuat, 2 = manis lemah, 1 = manis sangat lemah. 
dengan semakin tebal lapisan kemasan (Tabel 2). Hasil uji statistik menunjukkan bahwa ketebalan lapisan film kemasan edibel secara nyata memengaruhi tekstur nasi jagung $(\alpha=0,05)$. Kepulenan nasi jagung meningkat dengan semakin tebalnya lapisan kemasan karena semakin tinggi kandungan amilopektin pada kemasan.

Rasa nasi jagung dalam kemasan edibel berkisar antara manis sangat lemah sampai manis agak kuat (skor 1,3-2,8), di mana rasa manis meningkat dengan semakin tebalnya lapisan kemasan edibel (Tabel 3). Hasil uji Anova menunjukkan bahwa ketebalan lapisan kemasan edibel secara nyata memengaruhi rasa nasi jagung $(\alpha=0,05)$. Peningkatan kemanisan nasi jagung terjadi karena pada saat dipanaskan pati yang terdapat pada nasi jagung dan kemasan edibel akan dipecah menjadi gula sederhana. Peningkatan gula sederhana menyebabkan peningkatan rasa manis (BeMiller and Wistler, 2009). Semakin besar ketebalan film, rasa beras jagung kemasan film edibel cenderung semakin disukai. Tingkat kesukaan beras jagung kemasan film edibel yang semakin meningkat disebabkan karena peningkatan rasa kenyal akibat pertambahan ketebalan film tersebut (Yaniansah 2017).

Untuk mengetahui mutu nasi jagung yang paling disukai oleh panelis, dilakukan uji rangking. Tabel 3 menunjukkan bahwa beras jagung yang paling disukai berdasarkan kepulenannya adalah beras jagung dalam kemasan film edibel dengan ketebalan 1,5 mm. Hasil Anova menunjukkan bahwa ketebalan lapisan kemasan secara nyata memengaruhi uji rangking $(\alpha=$ 0,05).

\section{KESIMPULAN}

Hasil menunjukkan bahwa mutu beras jagung putih kering dalam kemasan secara nyata dipengaruhi oleh ketebalan lapisan kemasan edibel untuk parameter kadar air, kadar abu, kadar protein, kadar lemak, dan kadar karbohidrat. Ketebalan lapisan kemasan edibel secara nyata memengaruhi mutu nasi jagung yang dimasak untuk semua parameter $(\alpha=0,05)$ selain uji aroma. Nasi jagung terbaik berdasarkan uji kepulenan ditemukan pada nasi jagung yang dilapis dengan kemasan edibel ketebalan 1,5 mm. Karakteristik mutu beras jagung putih kering terbaik adalah kadar air $11,39 \%$, abu $0,21 \% \mathrm{db}$, protein $15,23 \% \mathrm{db}$, lemak $0,53 \%$, karbohidrat $72,64 \%$, dan serat kasar $2,11 \%$. Mutu nasi jagung yang sudah dimasak memiliki kepulenan 18,17 $\mathrm{g} / \mathrm{mm}^{2}$, dengan warna kekuningan (skor 1,1), aroma agak khas jagung (skor 2,5), tekstur agak pulen (skor 3,4 ), dan rasa manis agak kuat (skor $2,8)$.

\section{DAFTAR PUSTAKA}

[AOAC] Association of Official Analytical Chemist. 2006. Official Methods of Analysis of The
Association of Official Analytical Chemist (W. Horwitiz, Editor), 18th ed. Washington DC (US).

Avella M, De Vlieger JJ, Errico ME, Fischer S, Vacca P, Volpe MG. 2005. Biodegradable starch/clay nanocomposite films for food packaging applications. Food Chemistry. 93(3): 467-474. https://doi.org/10.1016/j.foodchem.2004.10.024

Badan Standarisasi Nasional. 1992. Cara Uji Makanan dan Minuman (SNI 01-2891-1992). Badan Standarisasi Nasional. Jakarta (ID).

Badan Standarisasi Nasional. 1994. Standar Nasional Indonesia: Tepung Tapioka (SNI 01-3451-1994). Badan Standarisasi Nasional, Jakarta (ID).

BeMiller J, Wistler R. 2009. Starch: Chemistry and Technology. 3rd edition. Oxford (UK): Academic Press is an imprint of Elsevier.

Bersaneti GT, Mantovan J, Magri A, Mali S, Celligoi MAPC. 2016. Edible films based on cassava starch and fructooligosaccharides produced by Bacillus subtilis natto CCT 7712. Carbohydrate Polymers. 151: 1132-1138. https://doi.org/10.1016/ j.carbpol.2016.06.081

Ekasari D. 2007. Modifikasi Pati Alami dan Pati Hasil Pemutusan Rantai Cabang dengan Perlakuan Fisik/Kimia untuk Meningkatkan Kadar Pati Resiten pada Pati Beras. [Skripsi]. Malang (ID): Jurusan Teknologi Hasil Pertanian Fakultas Teknologi Pertanian Universitas Brawijaya.

Farasara R, Hariyadi P, Fardiaz D, Dewanti-Hariyadi R. 2014. Pasting Properties of White Corn Flours of Anoman 1 and Pulut Harapan Varieties as Affected by Fementation Process. Food and Nutrition Sciences. 5: 2038-2047. https://doi.org/ 10.4236/fns.2014.521215

Galdeano MC, Wilhelm AE, Mali S, Grossmann MVE. 2013. Influence of Thickness on Properties of Plasticized Oat Starch Films. Braz. Arch. Biol. Technol. 56(4): 637-644. https:// doi.org/10.1590/S1516-89132013000400014

Husain H, Muchtadi TR, Sugiyono, Haryanto B. 2006. Pengaruh Metode Pembekuan dan Pengeringan terhadap Karakteristik Grits Jagung Instan. Jurnal Teknol. dan Industri Pangan. XVII(3): 189-196.

Imanningsih N. 2012. Profil gelatinisasi beberapa formula tepung-tepungan. Penel Gizi Makan. 35(1): 13-22.

Kemenkes RI. 2017. Tabel Komposisi Pangan Indonesia. Kementerian Kesehatan Republik Indonesia. Diakses 18 April 2020.

Lund MN, Ray CA. 2017. Control of Maillard Reactions in Foods: Strategies and Chemical Mechanisms. J. Agric. Food Chem. 65: 4537-4552. https://doi.org/10.1021/acs.jafc.7b00882

Mali S, Sakanaka LS, Yamashita F, Grossmann MVE. 
2005. Water sorption and mechanical properties of cassava starch films and their relation to plasticizing effect. Carbohydrate Polymers. 60: 283-289.

Marsh K, Bugusu B. 2007. Food packaging-Roles, materials, and environmental issues. J. Food Sci. 72: R39-R55.

Meilgaard M, Civille GV, Carr BT. 2015. Sensory evaluation techniques. 5th ed. CRC Press. https://doi.org/10.1201/b19493

Parreidt TS, Müller K, Schmid M. 2018. Alginate-Based Edible Films and Coatings for Food Packaging Applications. Foods. 7(170): 1-38. https://doi.org/10.3390/foods7100170

Peranginangin R, Handayani AM, Fransiska D, Djagal WM, Supriyadi. 2015. Pengaruh Konsentrasi $\mathrm{CaCl}_{2}$ dan Alginat terhadap karakteristik analog bulir jeruk dari alginat. JPB Kelautan dan Perikanan. 10(2): 163-172. https://doi.org/10.15578/jpbkp.v10i2.375

Qanytah, Prastuti TR. 2008. Penerapan Teknologi Pascapanen Jagung di Desa Kedawung Kecamatan Bojong Kabupaten Tegal. Dalam: Prosiding Seminar Nasional Teknik Pertanian. Yogjakarta (ID).

Rahmawati R, Dewanti-Hariyadi R, Hariyadi P, Fardiaz D, Richana N. 2013. Isolation and Identification of Microorganisms during Spontaneous Fermentation of Maize. Jurnal Teknologi dan Industri Pangan. 24(1):

33-39.

https://doi.org/10.6066/jtip.2013.24.1.33

Rahmawati R, Maulani RR, Saputra D. 2018. Chemical Properties, Particle Shape and Size of Fermented Local White Corn Flour of Anoman fs Variety. Jurnal Teknologi. $80 \quad$ (5): 155-161. https://doi.org/ 10.11113/jt.v80.11017

Resianingrum R, Atmaka W, Khasanah LU, Kawiji, Utami R, Praseptiangga D. 2016. Characterization of cassava starch-based edible film enriched with lemongrass oil (Cymbopogon citratus). Nusantara

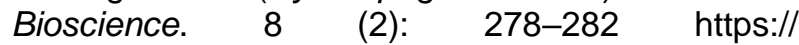
doi.org/10.13057/nusbiosci/n080223

Richana N, Ratnaningsih, Abdullah Bin Arif, Hayuningtyas M. 2011. Characterization of Eight Maize Varieties with a Low Glycemic Index to Support Food Security. Proceeding International Maize Conference. Frankfurt, 14-16 th June 2011

Richana N, Suarni. 2005. Teknologi Pengolahan Jagung. Prosiding Seminar dan Lokakarya Nasional Makasar 2005. Pusat Penelitian dan Pengembangan Tanaman Pangan: 391-393, 396.

Sanyang ML, Sapuan SM, Jawaid M, Ishak MR, Sahari J. 2016. Effect of plasticizer type and concentration on physical properties of biodegradable films based on sugar palm (Arenga pinnata) starch for food packaging. Journal of Food Science and
Technology. 53(1): 326-336.

Suarni, Firmansyah IU. 2005. Beras Jagung: Prosesing Dan Kandungan Nutrisi Sebagai Bahan Pangan Pokok. Prosiding Seminar dan Lokakarya Nasional Jagung. Makassar : 393-398.

Suarni, Widowati S. 2007. Struktur, komposisi, dan nutrisi jagung dalam Jagung: Teknik Produksi dan Pengembangan. Pusat Penelitian dan Pengembangan Tanaman Pangan, Bogor. HIm. 410-426.

Suarni, Firmansyah IU, Aqil M. 2013. Keragaman Mutu Pati Beberapa Varietas Jagung. Penelitian Pertanian Tanaman Pangan. 32(1): 50-56

Sugiyono, Soekarto ST, Hariyadi P, Supriadi A. 2004. Kajian Optimasi Teknologi Pengolahan Beras jagung. Jurnal Teknologi dan Industri Pangan. 15(2): 119-128.

Suyatma NE. 2010. Analisis Sifat Fisik-Texture Analysis. Departemen IImu dan Teknologi Pangan Institut Pertanian Bogor, Bogor.

U.S. Food and Drug Administration. 2019. Code for Federal Regulations Title 21 Part 184-Direct Food Substances Affirmed as Generally Recognized as Safe. Available online: https://www. accessdata.fda.gov/scripts/cdrh/cfdocs/cfcfr/CFRS earch.cfm?fr=184.1724 (diakses 13 April 2020).

Widowati S, Santoso BAS, Astawan M, Akhyar. 2009. Penurunan Indeks Glikemik Berbagai Varietas Beras melalui Proses Pratanak. Jurnal Penelitian Pascapanen Pertanian. 6(1): 1-9.

Wijaya DR. 2013. Pencirian Edible film Pati Tapioka Terplastisasi Sorbitol dengan Penambahan Natrium Alginat. [Skripsi]. Bogor (ID): Institut Pertanian Bogor.

Winarno FG. 1997. Kimia Pangan dan Gizi. Jakarta (ID): Gramedia.

Yaniansah A. 2017. Karakteristik mutu beras jagung dalam kemasan edibel dengan ketebalan film berbeda. [Skripsi]. Jakarta (ID): Universitas Sahid.

Yu AN, Li Y, Yang Y, Yu K. 2018. The browning kinetics of the non-enzymatic browning reaction in Lascorbic acid/basic amino acid systems. Food Science and Technology. 38(3): 537-542. https://doi.org/10.1590/1678-457x.08717

Zahiruddin SMM, Othman SH, Tawakkal ISMA, Talib RA. 2019. Mechanical and thermal properties of tapioca starch films plasticized with glycerol and sorbitol. Food Research. 3(2): 16-166. https://doi.org/10.26656/fr.2017.3(2).105

Zhang Y, Han JH. 2006. Plasticization of Pea Starch Films with Monosaccharides and Polyols. Journal of Food Science. 71(6): E253-E261. https:// doi.org/10.1111/j.1750-3841.2006.00075.x 